\title{
Pendidikan Islam Ramah Budaya: Pendekatan Filosofis
}

\author{
Muhammad Turmudzi ${ }^{1}$, Fatia Inas Tsuroya ${ }^{2}$ \\ 1 Program Pascasarjana Universitas Islam Negeri Sunan Kalijaga Yogyakarta \\ 2 Program Pascasarjana Universitas Islam Negeri Sunan Kalijaga Yogyakarta
}

Keywords:

Pendidikan, Islam, Budaya, Filosofis.

\begin{abstract}
Lately, the emergence of various problems in human life, especially in education. One of the issues or issues that are quite viral in this modern era is the fragility or in other words the shifting of Islamic values about tolerance towards all tribes and cultures. Therefore, the presence of this study aims to examine how the concept of Islamic education in overcoming various human problems or in the term "humanizing humanity" in the sense of Islamic education as a potential transaction process in culture related to specific Islamic values in dealing with ethnic, cultural differences, and various problems of human life, especially in education. By using a philosophical approach which is one branch of philosophy that discusses the nature of human knowledge. His philosophy is similar to Islamic education taught by the Prophet long before his preaching that did not look at ethnicity, religion, culture, and nation.
\end{abstract}

\section{PENDAHULUAN}

Era modern ini, pendidikan sebagai sebuah proses pengembangan sumberdaya manusia agar memperoleh kemampuan sosial dan perkembangan individu yang optimal memeberikan relasi yang kuat antar individu dengan masyarakat dan lingkungan budaya sekitar. ${ }^{1}$ Kemampuan sosial merupakan salah satu tujuan dalam pendidikan dikarenakan manusia adalah makhluk sosial. Ia tidak mampu hidup sendiri dalam berbagai hal, manusia membutuhkan bantuan orang lain. Oleh sebab itu, manusia harus hidup secara sosial. ${ }^{2}$ Lebih dari itu, pendidikan merupakan proses "memanusiakan manusia" dimana manusia diharapkan mampu memahami dirinya, orang lain,

1 Rustam Ibrahim, Pendidikan Multikultural: Pengertian, Prinsip, dan Relevansinya dengan Tujuan Pendidikan Islam, Jurnal Addin, Vol. 7, No. 1, Februari 2013, 131

2 Bukhari Umar, Hadis Tarbawi (Pendidikan Dalam Pespektif Hadis), (Jakarta, AMZAH:2012), 57 alam dan lingkungan budayanya. Atas dasar inilah pendidikan tidak terlepas dari budaya yang melingkupinya sebagai konsekwensi dan tujuan pendidikan yaitu mengasah rasa, cipta dan karya. Pencapaian tujuan pendidikan tersebut menjadi tantangan sepanjang masa karena salah satu tantangan dalam pendidikan adalah perbedaan suku dan budaya.

Kenyataan sekarang menunjukkan berbagai problem khususnya dalam pendidikan. Sebagai bangsa yang memiliki kekayaan budaya, Indonesia sangat membutuhkan perdamaian, keadilan, persamaan, dan seterusnya yang merupakan unsur yang dapat dilahirkan oleh pendidikan multikultural. Tetapi, patut dicatat bahwa akhir-akhir ini yang terjadi justru jauh dari harapan kemanusiaan yang mengedepankan nilai-nilai keadilan sosial, keharmonisan, keamanan, perdamaian, 
dan persaudaraan. ${ }^{3}$ Dengan kata lain politik, ekonomi, budaya dan pendidikan, semakin menggurita di negeri ini. Melihat secara luas diakui bahwa, Islam adalah agama yang dianut mayoritas penduduk Indonesia. Oleh sebab itu, Islam sebagai agama mayoritas sebenarnya berpeluang besar dalam mempengaruhi tata hidup kemasyarakatan dan kebangsaan di tanah air. ${ }^{4}$

Islam sendiri merupakan agama yang mengajarkan kedamaian, kesejahteraan, dan sikap toleran. Agama islam memberikan bimbingan kepada manusia mengenai semua aspek kehidupan. Agama Islam merupakan suatu sistem akidah dan syari'ah serta akhlak yang mengatur hidup dan kehidupan manusia dalam berbagai hubungan. Jika dicontohkan dalam agama lain misalnya agama Nasrani yang hanya mengatur hubungan manusia dengan Tuhan. Berbeda dengan agama Islam yang tidak hanya mengatur hubungan manusia dengan manusia dalam masyarakat termasuk dengan diri manusia itu sendiri tetapi juga dengan alam sekitarnya yang kini terkenal dengan istilah lingkungan hidup. ${ }^{5}$

Adapun dasar dan tujuan pendidikan Islam secara umum; diselenggarakan secara egaliter, demokratis, manusiawi, toleransi, dan berdasrkan ajaran luhur lainnya. Pendidikan diselenggarakan dengan menghargai hak anak didik dari manapun etnis, kultur, agama, atau kondisi ekonominya. Kepentingan anak

\footnotetext{
${ }^{3}$ Ruslan Ibrahim, Pendidikan Multikultural: Era Pluralitas Agama, Jurnal Pendidikan Islam, elTarbawi, No. 1, Vol. 1, 2008, 116

4 Mahmud Arif, Pendidikan Agama Islam Inklusif-Multikultural, Jurnal Pendidikan Islam:: Volume 1, Juni 2012/1433

5 Mohammad Daud Ali, Pendidikan Agama Islam, (Depok, Rajawali Pers: 2018), 51
}

didik menjadi kepentingan utama yang tidak boleh dikalahkan oleh atau demi kepentingan lainnya. ${ }^{6}$

Sementara itu, dalam Pasal 4 UU Nomor 20 Tahun 2003 disebutkan mengenai prinsip pendidikan sebagai berikut:

1. Pendidikan diselenggarakan secara demokratis dan keadilan serta tidak diskriminatif dengan menjujung tinggi hak asasi manusia, nilai keagamaan, nilai kultural dan kemajemukan bangsa.

2. Pendidikan diselenggarakan sebagai suatu kesatuan yang sistematis dengan sistem terbuka dan multimakna.

3. Pendidikan diselenggarakan sebagai suatu proses pembudayaan dan pemberdayaan peserta didik yang berlangsung sepanjang hayat. ${ }^{7}$

Dari prinsip di atas, jelas bahwa dalam proses pendidikan memiliki tujuan secara demokrasi bagi setiap peserta didik dalam mengem-bangkan kepribadian individu untuk hidup dalam sosial masyarakat yang toleran dalam mengahadapi perbedaanperbedaan yang ada.

Sikap saling menerima, menghargai nilai, budaya, keyakinan yang berbeda tidak otomatis akan berkembang sendiri. Apalagi karena dalam diri seseorang ada kecenderungan untuk mengharapkan orang lain menjadi seperti dirinya. Sikap saling menerima dan menghargai akan cepat berkembang bila dilatihkan dan dididikkan pada generasi muda dalam sistem pendidikan nasional. Dengan pendidikan, sikap penghargaan terhadap perbedaan yang direncanakan dengan baik, generasi muda dilatih

\footnotetext{
6 M. Bashori Muchsin dkk, Pendidikan Islam Humanistik; Alternatif Pembebasan Anak, (Bandung, PT Rafika Aditama: 2010), 9

${ }^{7}$ M. Bashori Muchsin dkk, 10
} 
dan disadarkan akan pentingnya penghargaan pada orang lain dan budaya lain bahkan melatihnya dalam hidup sehingga sewaktu mereka dewasa sudah mempunyai sikap itu (Paul Suparno, Kompas). ${ }^{8}$

Namun, Salah satu persoalan penting yang perlu dipertanyakan adalah bagaimana mengembangkan pendidikan Islam yang mengedepankan nilai-nilai sosial yang meliputi menghargai, keharmonisan, dan segala permasalahan kultur yang ada? atas pesoalan inilah penulis mencoba untuk menghadirkan tulisan ini dengan memberi fokus pada pendidikan Islam ramah buadaya dalam pendekatan filosfis.

\section{METODE PENELITIAN}

Penelitian ini menggunakan metode kualitatif yaitu melalui kajian literatur atau kepustakaan dan menganalisanya secara deskriptif (library research). Data-data utama yang digunakan bersumber dari bukubuku dan artikel-artikel yang relevan dengan penelitian. Adapun prosedur penelitian dilakukan dengan mendeskripsikan fenomena pendidikan Islam dalam konteks keberagaman dengan pendekatan filosofis.

\section{HASIL DAN PEMBAHASAN Konsep Pendidikan Islam}

Pendidikan merupakan elemen terpenting dari kehidupan yang sekaligus membedakan manusia dengan makhluk yang lain. Secara umum dapat dikatakan bahwa pendidikan adalah suatu proses yang didesain untuk memindahkan atau menularkan pengetahuan dan keahlian atas kecakapan serta kemampuan. Pemindahan atau penularan itu berlangsung terus menerus dari satu

\footnotetext{
${ }^{8}$ Ruslan Ibrahim, 117
}

generasi ke generasi berikutnya. ${ }^{9}$ Karena Bagi manusia, belajar merupakan rangkaian kegiatan menuju pendewasaan ke arah kehidupan yang lebih berarti. Manusia sebagai mahluk paedagogik ialah makhluk Allah yang dilahirkan membawa potensi dapat di didik dan mendidik, sehingga mampu menjadi pemimpin di bumi (Khaalifah fil al-ard), pendukung dan pengembang kebudayaan. Manusia di beri fitrah oleh Allah berupa wadah yang dapat diisi berbagai ketrampilan, yang dapat dikembangkan sesuai dengan kemampuan yang dimiliki. ${ }^{10}$

Begitupun pendidikan Islam dalam perspektif al-Attas adalah suatu proses penanaman sesuatu ke dalam diri manusia yang mengacu kepada metode dan sistem penanaman secara bertahap sedemikian rupa sehingga membimbingnya ke arah pengenalan dan pengakuan terhadap Khaliq Sang Pencipta, Allah Swt. ${ }^{11}$

Sedangkan menurut Abudin Nata Pendidikan Islam adalah Upaya membimbing dan membina peserta didik yang dilakukan secara sadar serta terencana agar memiliki kepribadian yang sesuai dengan nilai-nilai yang diajarkan oleh Islam. Pendidikan Islam dalam pandangan multikultural merupakan hasil dari pemikiran yang memerlukan sebuah evaluasi proses

\footnotetext{
${ }_{9}^{9}$ Ade Putra Panjaitan dkk, Korelasi Kebudayaan \& Pendidikan, (Jakarta: Yayasan Pustaka Obor Indonesia, 2014), 22.

10 Febri Santi, Konsep Pendidikan Multikultural Dalam Pendidikan Islam, Turast: Jurnal Penelitian \& Pengabdian Vol. 4, No. 1, Januari Juni 2016.

11 Mohammad David El Hakim \& Eni Fariyatul Fahyuni, Pendidikan Islam dalam Perspektif Syed Naquib Al-Attas dan Relevansinya bagi Pengembangan Pendidikan Islam di Indonesia, Islamika : Jurnal Keislaman dan Ilmu Pendidikan Volume 2, Nomor 1, Januari 2020.
} 
konversi dan transformasi ilmu pendidikan. ${ }^{12}$

Beberapa konsep pendidikan Islam diantaranya ialah tarbiyah, ta'lim, ta'dib. menurut kamus bahasa arab lafadz At-Tarbiyah bentuk dasar dari kata kerja rabba yang berasal dari kata raba-yarbuu yang memiliki pengertian dasar yaitu tumbuh dan berkembang. kedua rabiya-yarba kata ini mengikuti wazan khafiya-yakhfa yang berarti menjadi besar, ketiga rabba-yarubbu merupakan kata yang mengikuti wazan madda-yamuddu yang artinya memperbaiki, menguasai urusan, menuntun, menjaga, dan memelihara. Kata tarbiyah merupakan mashdar dari rabba-yurabbiy-tarbiyatan dengan mengikuti wazan fa'ala-yaf'ilu-taf'ilan. Kata ini ditemukan dalam QS. al-isra' ayat 24 yang memiliki arti "dan rendahkanlah dirimu terhadap mereka berdua dengan penuh kesayangan dan ucapkanlah: wahai tuhanku, kasihilah mereka keduanya, sebagaimana mereka berdua telah mendidikku waktu kecil". ketiga asal kata tersebut dapat disimpulkan bahwa tarbiyah memiliki empat elemen yaitu : menjaga dan memelihara fitrah anak menjelang baligh, mengembangkan seluruh potensi dan kesiapan yang bermacammacam, mengarahkan seluruh fitrah dan potensi anak menuju kepada kebaikan dan kesempurnaan yang layak baginya, proses ini dilaksanakn secara bertahap. ${ }^{13}$

12 Febri Santi, Konsep Pendidikan Multikultural Dalam Pendidikan Islam, Turast: Jurnal Penelitian \& Pengabdian Vol. 4, No. 1, Januari Juni 2016.

13 Dedi Wahyudi \& Siti Aisah, Aktualisasi Pendidikan Islam Dalam Pengelolaan Lingkungan HidupP: Studi Relasi Antara Pendidikan Islam dan Budaya Mistis Dalam Pelestarian Lingkungan, Tarbawiyah: Jurnal Ilmiah Pendidikan :: Volume 02; Nomor 01, Juni 2018 p-ISSN: 2579-3241; e-ISSN: 2579-325X.
Ta'lim adalah proses pemberian pengetahuan, pengertian, pemahaman, tanggung jawab, dan penanaman amanah, sehingga terjadi penyucian atau pembersihan diri manusia dari segala yang tidak baik yang untuk menjadi baik serta mempelajari segala sesuatu yang bermanfaat dan yang tidak diketahuinya. ${ }^{14}$

Pada zaman klasik manusia hanya tau dan mengenal istilah ta'dib untuk menunjukkan kegiatan pendidikan. Pengertian ini terus menerus dipakai sepanjang masa kejayaan Islam, sehingga semua ilmu pengetahuan yang dihasilkan oleh akal manusia pada masa itu disebut adab, baik itu yang memiliki hubungan dengan Islam ataupun tidak. Seorang pendidik pada masa itu disebut mu'addib. Ta'dib merupakan suatu pengenalan yang terjadi secara berangsur-angsur ditanamkan kepada manusia tentang tempat-tempat yang tepat sedemikian rupa, sehingga dapat membimbing ke arah kekuasaan dan keagungan tuhan. ${ }^{15}$

\section{Epistemologi Islam}

Makna epistemologi adalah salah satu cabang filsafat yang membahas tentang hakikat penge-tahuan manusia. Persoalan pokok yang berkembang dalam epistemologi adalah meliputi sumber-sumber pengetahuan, watak dari pengetahuan manusia, apakah

14 Dedi Wahyudi \& Siti Aisah, Aktualisasi Pendidikan Islam Dalam Pengelolaan Lingkungan HidupP: Studi Relasi Antara Pendidikan Islam dan Budaya Mistis Dalam Pelestarian Lingkungan, Tarbawiyah: Jurnal Ilmiah Pendidikan :: Volume 02; Nomor 01, Juni 2018 p-ISSN: 2579-3241; e-ISSN: 2579-325X.

15 Dedi Wahyudi \& Siti Aisah, Aktualisasi Pendidikan Islam Dalam Pengelolaan Lingkungan HidupP: Studi Relasi Antara Pendidikan Islam dan Budaya Mistis Dalam Pelestarian Lingkungan,Tarbawiyah: Jurnal Ilmiah Pendidikan :: Volume 02; Nomor 01, Juni 2018 p-ISSN: 2579-3241; e-ISSN: 2579-325X. 
pengetahuan itu benar (valid) ataukah tidak. Bagaimana pengetahuan manusia itu didapat, dengan cara apa dan apa saja syarat-syarat yang harus dipenuhi. Sehingga epistemologi sampai pada problem hubungan metodologi dengan obyek dari ilmu pengetahuan. ${ }^{16}$

Sementara dalam lingkungan studi Islam, istilah epistemologi sering dipertukarkan dengan istilah pemikiran. Pemikiran berasal dari kata pikir yang berarti akal budi, ingatan, angan-angan, sehingga pemikiran berarti proses, cara, perbuatan memikir. Dalam Kamus Besar Ilmu Pengetahuan, pikiran berarti suatu entitas yang memperlihatkan fungsifungsi seperti menyerap, mengamati, mengingat memungkinkan manusia merefleksikan dunia obyektif ke dalam tataran konsep, putusan dan teori lewat proses abstraksi, analisis, sintesis, pemecahan dan hipotesis. Menurut Michel Foucault, sebagaimana dikutip Johan Meuleman dalam kata pengantar penebitan karya Arkoun, pemikiran berarti pemahaman dan pandangan seseorang terhadap suatu objek (kenyataan). Pemahaman tersebut meliputi apa yang dianggap penting dan tidak penting, hubungan apa yang diadakan antara berbagai unsur kenyataan dalam penggolongan dan analisis, dan lain sejenisnya.

Dengan demikin pemikiran juga termasuk studi yang menekuni hal-hal yang fundamental dalam pengetahuan yaitu paradigma kefilsafatan yang menyangkut asumsi dasar yang disusun sebagai landasan dan kerangka dari suatu bangunan keilmuan. Asumsi dasar tersebut termasuk hal-hal yang diorientasikan untuk memecahkan berbagai persoalan menyangkut

16 Anwar Mujahidin, Epistemologi Islam: Kedudukan Wahyu Sebagai Sumber Ilmu, Jurnal Ulumuna Studi Islam Volume 17 Nomor 1 (Juni) 2013, hal.5 hubungan subyek dan obyek, tolak ukur validasi keilmuan dan prinsipprinsip dasar lainnya.

Berkaitan dengan pembangunan ilmu yang Islami, belakangan muncul upaya Islamisasi ilmu pengetahuan sebagai jawaban terhadap perkembangan pengetahuan yang dianggap jauh dari ajaran dan berbagai persoalan dalam dunia pendidikan maupun kehidupan manusia yang mulai mengalami tergesernya nila-nilai Islam. ${ }^{17}$

Islamization of knowledge yang dikembangkan oleh sebagian pemikir muslim, ada yang memulai sejak epistemologinya, ada pula yang hanya membicarakan aksiologinya saja. Khusus natural science sukar dikembangkan epistemologi tersendiri yang berbeda dengan apa yang telah ditemukan oleh ahli natural science selama ini, sebab hal-hal yang terkait kealaman hukumnya tetap tidak berubah (la tabdila li sunnatillah). Untuk hal ini Tuhan tidak banyak memberikan petunjuk karena alam selalu berjalan sesuai dengan aturan atau takdir Tuhan. Sementara yang terkait dengan manusia di luar fisika, biologi dan kimia manusia, maka tidak ada hukum yang tetap, karena manusia melalui akal pikiran dan perasaannya selalu berubah dan berkembang sesuai dengan situasi dan kondisi yang sedang dihadapinya. Manusia memiliki hak pilih, oleh sebab itu Tuhan menurunkan qauliah-Nya (Al-quran maupun Sunnah) yang berisi petunjuk berbagai aspek kehidupan kemanusiaan baik isu-isu ibadah, isu-isu muamalah seperti isu ekonomi, sosial, budaya, politik dan sebagainya termasuk isu pendidikan. Petunjuk qauliah Tuhan umumnya bersifat

\footnotetext{
${ }^{17}$ Kamrani Buseri, Epistemologi Islam dan Reformasi Wawasan Pendidikan, Jurnal Ilmiah Peuradeun,Vol. 3, No. 1, January 2015, hal.78
} 
deduktif, normatif, motivatif, inovatif, reflektif, isyarah, hudan, bayan dan furqan. 18

Epistemologi Islam perlu dijadikan alternatif terutama bagi fisosof pemikir dan ilmuan Muslim untuk menyelamatkan mereka dari keterjebakan ke dalam arus besar dibawah kendali epistemologi Barat. Sekarang ini epistemologi Barat menguasai seluruh wilayah dunia, sehingga tidak mempedulikan adanya alternatif-alternatif epistemologi lain. Para ilmuan Muslim juga mengikuti bahkan tidak jarang yang mengandalkan epistemologi Barat tanpa koreksi sama sekali, maka secara intelektual sebenarnya umat Islam menjadi terjajah oleh Barat.

Kondisi umat Islam sekarang ini sungguh memprihatinkan. Secara politik mereka dipermainkan oleh kekuatan Barat, secara sosial mereka mengenaskan, secara ekonomi mereka terbelakang, dan secara intelektual mereka hanya menjadi konsumen yang terlambat. ${ }^{19}$ Kalaulah mereka mendalami ilmu pengetahuan, mereka terlelap dalam lingkaran pengaruh paradigma berpikir, tradisi dan kultur ilmiah Barat yang dalam beberapa hal bertentangan dengan Islam.

Epistemologi ini terbukti mampu mengantarkan zaman klasik Islam menuju pada kemampuan membangun ilmu dan kebudayaan yang tidak dikotomik. Al-Ghazali, misalnya telah memberikan pondasi yang kuat bagi tegaknya epistemologi Islam pada zamannya dan bersifat aplikatif. Dia menyatakan, "perkembangan sains yang berakar pada epistemologi dan sistem nilai Islam-sebuah sains yang dapat diinternalisasikan dan bisa mengekspresikan tanggung jawab

18Kamrani Buseri, 79

19 Mujamil Qomar, Epistemologi Pendidikan Islam, (Jakarta, Penerbit Erlangga: 2006), 164 sosial kaum Muslim-sungguh akan menjadi sebuah kebutuhan yaang mendesak. ${ }^{20}$

Epistemologi Islam ini memiliki fungsi yang sangat penting dalam menjaga kehormatan umat Islam. epistemologi ini bisa membangkitkan umat Islam untuk segera mencapai kemajuan ilmu pengetahuan dan secara umum peradaban, mengingat bahwa epistemologi tersebut merupakan media atau alat untuk menggali, menemukan dan mengembangkan pengetahuan.

Perwujudan epistemologi ini memang perlu segera diterapkan dengan pertimbangan epistemologi akan memberikan suatu aspek perilaku individual, societal dan civilisasional. Tanpa epistemologi yang jelas, mustahil muncul suatu peradaban.

Dari paparan pentingnya epistimologi Islam di atas sebagai pengantar bahwa, kaitannya dalam pendidikan Islam perlu kita melihat ke belakang bagaimana agama Islam dalam menjalankan nilai-nilai dalam pendidikan seperti menanamkan rasa sosial. Sikap toleransi dan berbagai persoalan tentang kehidupan sosial masyarakat.

Epistemologi Islam adalah bagaimana Islam menelorkan ilmu pengetahuan atau teori kebenaran, menyangkut metode, kemungkinankemungkinan, asal mula, sifat alami, batas, batas asumsi dan landasan serta bagaiman prosedurnya seperti tingkat validitas dan realibilitas. Epistemologi dalam konteks pendidikan Islam yaitu bagaimana Islam membahas isu memanusiakan manusia menjadi manusia menurut pandangan Islam

\footnotetext{
${ }^{20}$ Mujamil Qomar, 165
} 
sehingga memerlukan pendidikan Islam. $^{21}$

Hemat penulis terkait pengertian epistemologi Islam kita dapat menyesuaikan bagaiamana pendidikan Islam era modern yang tentunya harus mampu dikonteks-tualisasikan dengan ajaran-ajaran Islam. Di samping itu, perlu kita tanamkan kepada anak, peserta didik umumnya kepada manusia dalam membangun pendidikan Islam yang ramah akan budaya. Dalam pendidikan Islam tidak hanya mengarah pada satu tujan. Akan tetapi, yang terpenting dalam salah satu tujuan untuk kehidupan manusia adalah saling menghargai dengan sikap toleransi terhadap sesama.

\section{Tugas dan Fungsi Pendidikan Islam}

Secara umum tugas pendidikan Islam adalah membimbing dan mengarahkan pertumbuhan dan perkembangan peserta didik dari satu tahap ke tahap selanjutnya sampai mencapai titik kemampuan yang optimal. Sementara fungsinya adalah menyediakan fasilitas yang dapat memungkinkan tugas pendidikan berjalan dengan lancar.

Telaah literatur di atas, dapat dipahami bahwa, tugas pendidikan Islam setidaknya dapat dilihat dari tiga pendekatan. Ketiga pendekatan tersebut adalah:

Pendidikan Islam sebagai pengembangan potensi, proses pewarisan budaya, serta intraksi antar potensi dan budaya. Sebagai pengembangan potensi, tugas pendidikan Islam adalah menemukan dan mengembangkan kemampuan dasar yang dimiliki peserta didik, sehingga dapat diaktualisasikan dalam kehidupan sehari-hari.

21 Kamrani Buseri, Epistemologi Islam dan Reformasi Wawasan Pendidikan, Jurnal Ilmiah Peuradeun Vol. 3, No. 1, Januari 2015, 78
Sementara sebagai pewaris budaya, tugas pendidikan Islam adalah alat transmisi unsur-unsur pokok budaya dari satu generasi ke generasi berikutnya, sehingga identitas umat tetap terpelihara dan terjamin dalam tantangan zaman. ${ }^{22}$ Adapun sebagai interaksi anatara potensi dan budaya, tugas pendidikan Islam adalah sebagai proses transaksi (memberi dan mengadopsi) antara manusia dan lingkungannya. Dengan proses ini, peserta didik (manusia) akan dapat menciptakan dan mengembangkan keterampilan-keterampilan yang diperlukan untuk mengubah dan memperbaiki kondisi-kondisi kemanusiaan dan lingkungannya.

Mahmud Yunus merumuskan tujuan tugas dan fungsi pendidikan agama Islam yaitu:

1. Menanamkan rasa cinta dan ta'at kepada Allah subhannahu wata'ala.

2. Menanamkan i'tikad yang yang benar dan kepercayaan yang sesuai dengan tuntunan agama.

3. Mendidik untuk selalu mengikuti perintah Allah dan meninggalkan larangannya.

4. Mendidik untuk membiasakan berakhlak mulia dan adat kebiasaan yang baik.

5. Mengajarkan manusia/peserta didik umtuk mengetahui macammacam ibadah dan cara melaksanakannya serta mengetahui hikmah, faedah, dan pengaruh dari ibadah tersebut dalam pencapaian kebahagiaan dunia dan akhirat.

6. Memberi petunjuk hidup di dunia dengan baik dan bahagia di akhirat.

7. Memberikan contoh dan suri tauladan yang baik serta pengajaran dan nasehat.

22 Samsul Nizar, Filasaft Pendidikan Islam Pendekatan Historis, Teoritis dan Praktis, (Jakarta, Ciputat Pers: 2002), 33 
8. Membentuk warga negara yang baik dan masyarakat yang baik, berbudi luhur dan berakhlak mulia serta berpegang teguh dengan ajaran agama.

Pada hakikatnya tujuan pendidikan Islam adalah idelaitas (citacita), yaitu idealitas yang mengandung nilai-nilai Islami yang mana itu semua dicapai dalam proses kependidikan yang berdasarkan ajaran Islam secara bertahap. Dalam hal ini Arifin menyampaikan, bahwa pendidikan Islam merupakan penggambaran nilainilai islami yang berhak diwujudkan dalam pribadi manusia didik pada akhir dari proses sebuah pendidikan. ${ }^{23}$ Sedangkan Muhammad Athiyyah menyimpulkan bahwa tujuan pendidikan dan pengajaran bukanlah sebatas memenuhi otak anak didik dengan segala macam ilmu yang belum mereka ketahui, melainkan: 1) Mendidik akhlaq dan jiwa anak; 2) Menanamkan rasa keutamaan; 3) Membiasakan mereka dengan kesopanan yang tinggi; dan 4) Mempersiapkan mereka untuk suatu kehidupan dengan penuh keihklasan dan kejujuran. ${ }^{24}$

Sumber dari sistem ajaran Islam adalah al-Quran dan As-Sunnah. Rasulullah mengajarkan Al-Qur'an sebagai sumber dari materi pendidikan yang disampaikan kepada kaum muslim dan menjadikan Alquran satusatunya sebagai manhaj dan pusat pemikiran. ${ }^{25} \mathrm{Al}$-qur'an sebagai sumber utama sudah tidak diragukan lagi, karena keberadaan Al-qur'an telah

\footnotetext{
23 Bashori, Pemikiran Pendidikan Syekh Nawawi Al-Bantani, HIKMAH: Jurnal Pendidikan Islam, Vol. 6, No. 1 Januari-Juni 2017, 37-58

24 Muhammad 'Atthiyyah AL-Abrasyi, PrinsipPrinsip Dasar Pendidikan Islam (Bandung: Pustaka Setia, 2003), 13.

25 Choirul Mahfud, Sejarah Sosial Pendidikan Islam pada Era Ke Nabian
}

mempengaruhi sistem pendidikan Rasulullah SAW dan para sahabat. Terlebih ketika Aisyah istri Rasulullah menyampaikan bahwa akhlaq Rasulullah adalah Al-qur'an. Ditegaskan lagi dalam firman Allah: Artinya: Berkatalah orang-orang yang kafir: "Mengapa Al Quran itu tidak diturunkan kepadanya sekali turun saja?"; demikianlah, supaya Kami perkuat hatimu dengannya dan Kami membacanya secara tartil (teratur dan benar). (AlFurqan : 32). ${ }^{26}$ Sumber kedua, yaitu As-Sunnah. Adapun Amalan yang dikerjakan Rasulullah saw dalam kehidupan sehari-hari, juga dijadikan sumber utama dalam pendidikan Islam karena Allah telah menjadikan Muhammad sebagai Nabi dan teladan bagi umatnya.

Hakikat tujuan pendidikan Islam adalah untuk menjadikan manusia sebagai 'abdi Allah atau hamba Allah. Pendidikan seharusnya bertujuan menciptakan pertumbuhan yang seimbang dari kepribadian total manusia yakni dengan berbagai latihan spiritual, intelektual, rasional, perasan bahkan kepekaan tubuh manusia. Oleh karena itu, pendidikan semacam ini memerlukan suatu usaha dan pemikiran yang keras dan serius dalam upaya mewujudkan cita-citanya. Karenanya, pendidikan seharusnya menyediakan jalan bagi pertumbuhan potensi manusia dalam segala aspek; spiritual, intelektual, imajinatif, fisikal, ilmiah, linguistik, dan lain-lain.) baik secara individual, masyarakat dan manusia pada umumnya. ${ }^{27}$

\footnotetext{
${ }^{26}$ Ahmad Wahyu Hidayat, Pemikiran Syekh Nawawi Al-Bantani dan Relevansinya di Era Modern, JURNAL AQLAM - Journal of Islam and Plurality-Volume 4, Nomor 2, Desember 2019. 27 Robiatul Awwaliyah \& Hasan Baharun, Pendidikan Islam Dalam Sistem Pendidikan Nasional Robiatul Awwaliyah \& Hasan Baharun (Telaah Epistemologi Terhadap Problematika
} 


\section{Pewarisan Nilai-nilai Budaya}

Secara historis penggunaan istilah kebudayaan di Indonesia muncul pada sekitar tahun 1920 ketika semangat kebangsaan sedang bangkit. Tidak diketahui secara pasti siapa yang mengusulkan penggunaan istilah tersebut. Akan tetapi, menurut sebagian orang, yang mengusulkannya adalah Mangkunegoro VII. Motif pengguunaan istilah itu terkait dengan kondisi bangsa Indonesia yang masih dijajah oleh Belanda. ${ }^{28}$

Dalam bahasa Belanda dikenal istilah cultuure, dalam bahasa Inggris dikenal istilah culture, dan bahasa Jerman dikenal dengan istilah kultur. Secara etimologi ketiganya berasal dari verba dalam bahasa Latin, yaitu colore yang semula berarti "mengusahakan tanah", 'memelihara tanah' atau menggarap tanah agar dapat ditanami. Dalam perkembangaannya, istilah itu dipakai untuk semua usaha pertanian, perkebunan, dan kehutanan. Dalam bahasa Jawa ada istilah kabudidaya yang searti dengan colore karena pada hakikatnya otak manusia sama dengan tanah yang perlu dipelihara dan diolah agar bisa menghasilkan sesuatu. Agar keduua istilah tersebut mengandung makna yang sepadan, Mangkunegoro VII mengusulkan kata kabudidaya dengan menghilangkan suku kata $d i$ sehingga menjadi kebudayaan.

Antara pendidikan dan kebudayaan memiliki hubungan yang sangat erat. Keeratan hubungan itu sering diibaratkan seperti dua sisi mata uang. Sisi yang satu akan memiliki makna apabila dilengkapi dengan sisi yang sebelahnya. Demikian sebaliknya. Dilihat dari sisi pendidikan, hampir seluruh materi yang diberikan dalam

Pendidikan Islam), Jurnal Ilmiah DIDAKTIKA Vol. 19, No. 1, 2018, 34-49.

28 Suyuthi Pulungan, Sejarah Peradaban Islam, (Jakarta, Amzah:2018), 13 proses pendidikan pada hakikatnya adalah kebudayaan. Sebaliknya dari sisi kebudayaan, pelestarian kebudayaan pada hakikatnya dicapai melalui proses pendidikan. Melalui pendidikan segala hal yang terkandung dalam kebudayaan dari suatu generasi ditransfer dan di transformasikan ke generasi berikutnya. Demikian, proses itu akan berlangsung secara terus menerus sehingga yang dapat disaksikan melalui pendidikan, kebudayaan suatu bangsa tetap lestari. Oleh karena itu, pendidikan sering disebut proses pembudayaan. ${ }^{29}$

Kesesuaian pendidikan islam dengan nilai-nilai budaya nampak pada kerjasama antara keduanya. Kerjasama tersebut adalah pendidikan islam sebagai aktivitas, sedangkan isinya adalah nilai-nilai budaya Islam ataupun nilai-nilai budaya lainnya. ${ }^{30}$

Kata Kebudayaan didefinisikan untuk pertama kali oleh E.B.Taylir pada tahun 1871, dalam buku Primitive Culture dimana kebudayan diartikan sebagai keseluruhan yang mencakup pengetahuan, kepercayaan, seni, moral, hukum, adat serta kemampuan dan kebiasaan lainnya diperoleh manusia sebagai anggota masyarakat. Kuntjaraningrat secara lebih terperinci membagi kebudayan menjadi unsurunsur yang terdiri dari sistem religi dan upacara keagamaan, sistem dan organisasi kemasyarakatan, sitem pengetahuan, bahasa, kesenian, sistem mata pencaharian serta sistem teknologi dan peralatan. Manusia yang merupakan makhluk sosial tentunya dapat diartikan sebagai makhluk yang berkelompok dan bagian dari kelompok tersebut. Manusia yang tidak

\footnotetext{
${ }^{29}$ Sumihara, Pendidikan Islam dengan Nilai-nilai Budaya, Jurnal Adabiyah Vol. XII Nomor 2/2012.

${ }^{30}$ Sumihara, Pendidikan Islam dengan Nilai-nilai Budaya, Jurnal Adabiyah Vol. XII Nomor 2/2012
} 
hanya dianugrahi akal sebagai pontensi diri oleh Allah Swt, juga di berikan indarawi, nafs, intusi. Dengan adanya nafs dalam diri manusia menghadirkan keberaneka ragam keinginan dan kebutuhan dalam dirinya, untuk meredam dan mengelola keragaman keingianan dan kebutuhan manusia dibutuhkanlah sistem yang terorganisir dan terencana sehingga menghasilkan kesepakatan yang dapat mengikat dan menjadi identitas. Identitas yang telah disepakati bersama akan mencerminkan karakter dari masyarakat yang ada disuatu wilayah atau bangsa. Semakin kuat karakter yang dimiliki suatu bangsa akan menjadikan bangsa yang kuat dan beridentitas, kekuatan identitas suatu bangsa mejadikan bangsa yang berbudaya. Bangsa yang memiliki budaya adalah bangsa yang besar, bangsa yang besar akan berbanding lurus dengan intektulitas yang dimiliki masyarakat yang ada. Ashley Montagu berpendapat, Kebudayan mencermin-kan tanggapan masyarakat terhadap kebutuhan dasar hidupnya. Dengan kebudayan inilah yang membedakan manusia sebagai mahluk yang sempurna di ciptakan Allah Swt, dengan akal budi yang dimilikinya sebagai salah satu alat untuk menjadi khalifah dimuka bumi dengan memaksimalkan pontesi sebagai anugrah terbesar dalam diri manusia. $^{31}$

Alfed Korsybski berpendapat
bahwa kebudayaan mempunyai
kemampuan mengikat waktu. Dari semua makhluk ciptaan Tuhan, hanya manusialah yang mampu membudayakan kebudayaan yang ada dari generasi satu ke genarsi yang akan datang dan seterusnya. Tanaman mengikat bahanbahan kimiawi, binatang mengikat

31 Leni Nurmiyanti, Pendidikan Agama Islam Sebagai Pondasi Sosial Budaya Dalam Kemajmukan, ISTIGHNA, Vol. 1, No 2, 2018, 44 ruang, tetapi hanya manusia yang mampu mengikat waktu, dengan demikian hanya manusialah yang mampu menciptakan peradaban dan membudayakan kebudayaan dalam tatanan hubungan sosial masyarakat. ${ }^{32}$

Peran dan fungsi pendidikan Islam tidaklah kecil, artinya pendidikan harus menyiapkan manusia yang mampu mengadopsi teknologi, mampu memberikan kontribusi nilai tambah per-kapita yang tinggi, dan mampu hidup dalam struktur sosial budaya dan fungsi sosial yang kompleks. ${ }^{33}$

Pendidikan Islam bila ditinjau dari sudut pandang sosial budaya akan menempati pusat dan ruang lingkup wilayah, meliputi; 1) hubungan sekolah dan masyarakat; 2) peranan guru di masyarakat; 3) peranan sekolah di masyarakat; 4) faktor-faktor sosial budaya yang mempengaruhi sekolah; 5) pengaruh praktik pendidikan modern terhadap kepribadian; 6) modifikasi kurikulum dalam menjawab tantangan sosial; 7) pengertian tentang trend kebudayaan dan sosial yang berkaitan dengan lembaga pendidikan sekolah dan luar sekolah; 8) pendekatan proses kelompok sosial terhadap pendidikan; 9) pemanfaatan penelitian dan pemikiran kritis untuk menetapkan tujuan pendidikan. ${ }^{34}$

Dari rumusan di atas, dapat disimpulkan bahwa fungsi pendidikan agama Islam adalah pembinaan pribadi Muslim yang terpadu pada perkembangan seseorang, baik dari segi spritual, jasmani, emosi, intelektual dan sosial. Maka, oleh sebab itu berbicara pendidikan agama Islam baik tugas maupun fungsi harus mengacu pada

\footnotetext{
32 Nurmiyanti, 45

33 Akhmad Syarief Kurniawan, Tantangan Pendidikan Islam dan Budaya Lokal Pada Era Globalisasi di Indonesia, Tarbawiyah, Jurnal Ilmiah Pendidikan, Vol. 01 No.1, 2017, 33

${ }^{34}$ Kurniawan, 34
} 
penanaman nilai-nilai Islam dan tidak dibenarkan melupakan sosial atau moralitas sosial. ${ }^{35}$

\section{Ajaran Hidup Toleransi dalam Islam}

Islam merupakan agama yang mengajarkan untuk saling menghargai dan saling tolong menolong dalam menjalankan kehidupan di dunia. Akan tetapi, jika sebaliknya mereka yang memusuhi dan memerangi Islam harus ditindak secara tegas, agar mereka mengetahui secara jelas bahwa Islam agama yang menghargai persaudaraan, toleran kepada semua pemeluk agama selama tidak diganggu atau dimusuhi. ${ }^{36}$

Wujud toleransi ini semakin dikuatkan dengan kebijakan bahwa tidak ada paksaan dalam beragama. Nabi Muhammad, dan begitu juga para ulama sebagai pewarisnya hanyalah sebagai pemberi kabar, bukan pemaksa. Allah berfirman:

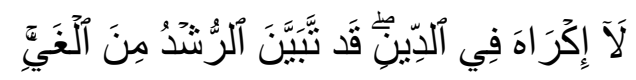

"Tidak ada paksaan untuk (memasuki) agama (Islam); Sesungguhnya Telah jelas jalan yang benar daripada jalan yang sesat" (QS. al- Baqarah: 256)

Islam agama yang terbuka, oleh karena itu sikap toleransi dan mau mengakui adanya berbagai macam perbedaan ditanamkan kepada umat Islam dan sebagai landasan pemikiran ini adalah firman Allah dalam QS. alHujurat ayat 13:

\footnotetext{
${ }^{35}$ M. Yasyakur, Strategi Guru Pendidikan Agama Islam Dalam Menanamkan Kedisiplinan Beribadah Sholat Lima Waktu, , Edukasi Jurnal Pendidikan Islam Vol. 05, 2016, 10

${ }^{36} \mathrm{Abu}$ Bakar, Konsep Toleransi dan Kebebasan Beragama, Jurnal TOLERANSI: Media Komunikasi Umat Bergama, Vol.7, No. 2, 2015, 5
}

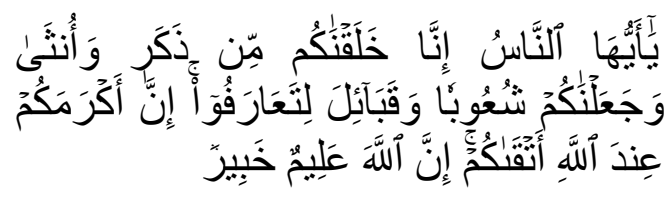

"Hai manusia, Sesungguhnya kami menciptakan kamu dari seorang laki-laki dan seorang perempuan dan menjadikan kamu berbangsabangsa dan bersuku-suku supaya kamu saling kenalmengenal. Sesungguhnya orang yang paling mulia di antara kamu di sisi Allah ialah orang yang paling taqwa di antara kamu. Sesungguhnya Allah Maha mengetahui lagi Maha Mengenal".

Beberapa ayat di atas secara sederhana mengakui eksistensi agama lain, meskipun dengan catatan, sesungguhnya Islam dalam pandangan kaum Muslimin, merupakan satusatunya agama yang hak. Di mana kaum muslimin meyakini bahwa hanya Islam yang paling benar, dengan sendirinya menafikan agama-agama lain. Namun, Islam sebagai agama yang damai dan menebarkan sikap kasih sayang, selalu menjaga hubungan baik dengan semua pemeluk agama dan menghormati kepercayaan orang lain, tidak seperti apa yang digambarkan oleh beberapa kalangan yang tidak senang dengan Islam. Sikap toleransi beragama bukan berarti harus membenarkan keyakinan pemeluk agama lain atau harus meyakini bahwa semua agama merupakan jalan yang benar dan direstui. Namun, yang dibutuhkan dalam toleransi adalah sikap saling menghargai terhadap pilihan orang lain dan eksistensi golongan lain, tidak perlu sampai membenarkan sebuah kepercayaan, kebenaran hanya milik masing-masing pemeluk agama. Pluralisme agama, yang membenarkan semua bentuk agama sebagai sarana yang benar menuju Tuhan menurut 
keyakinan masing-masing, namun yang demikian itu dapat mengaburkan prinsip dan lebih menonjolkan pribadi masing-masing pemeluk agama.

Persaudaraan yang sebenarnya ialah perhubungan manusia secara berkelanjutan dan menjaga persaudaraan tanpa melihat warna kulit, keturunan, kekayaan, bangsa dan sebagainya. ${ }^{37}$ Dengan kata lain, persauadaraan yang di ajarkan Islam tidak memilih bulu terlebih dalam melaksanakan pendidikan, Islam sangat toleran terhadap agama-agama lain terlebih dalam persaudaraan sesama muslim sendiri semuanya bersaudara sebagaimanafirman Allah:

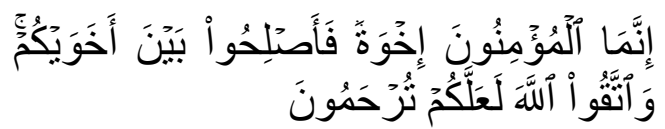

"Sesungguhnya sesama mukmin itu bersaudara, maka perdamaikanlah atau berbaik-baiklah diantara kamu, dan takutlah kepada Allah mudah-mudahan kamu mendapat rahmat. (Q.S. Al-Hujurat: 49:10)

Berdasarkan al-qur'an dan hadis sangat jelas Islam menganjurkan manusia hidup dalam keadaan aman dan damai. Merujuk situasi di sekolah misalnya, hubungan pelajar dengan pelajar serta pelajar dengan guru adalah dalam keadaan baik. Sekiranya pelajar dalam kalangan Islam mengamalkan dan menghayati Islam sepenuhnya maka akan mudah dalam menghadapi persoalan perbedaan suku, adat dan sebagainya. ${ }^{38}$

\section{KESIMPULAN}

37 Khalim Zaenal \& Wan Zulkifli Wan Hassan, Pendekatan Islam Dalam Menangani Masalah Disiplin Tegar dalam Kalangan Pelajar Ssekolah: Kajian Kes, Journal of Islamic and Arabic Education, 1 (2) 2009, 3

38 Zaenal dan Hassan, 4
Dari berbagai sub bahasan yang tercantum dalam tulisan terkait bagaiamana konsep pendidikan Islam, epistemologi Islam, dan beberapa sub yang merupakan dari ajaran Islam di atas penulis menyimpulkan bahwa, pendidikan merupakan salah satu usaha sadar yang direncanakan dan dilaksanakan secara berkesinambungan dengan tujuan untuk mengembangkan potensi manusia dalam berintaksi dalam kehidupan manusia. Islam sendiri merupakan agama yang mengajarkan kedamaian, kesejahtraan, dan sikap toleran. Agama islam memberikan bimbingan kepada manusia mengenai semua aspek kehidupan. Agama Islam merupakan suatu sitem akidah dan syari'ah serta akhlak yang mengatur hidup dan kehidupan manusia dalan berbagai hubungan. Kemudian, pentingnya pendekatan filosofis yaitu suatu ilmu filsafat yang identik dalam berfikir untuk kita mengamati pendidikan Islam secara mendalam secara Islam kita mengembangkan akal atau ilmu pengetahuan.

\section{REFERENSI}

Panjaitan, Ade Putra, et.al, Korelasi Kebudayaan \& Pendidikan, (Jakarta: Yayasan Pustaka Obor Indonesia, 2014)

Kurniawan, Akhmad Syarief, Tantangan Pendidikan Islam dan Budaya Lokal Pada Era Globalisasi di Indonesia, Tarbawiyah, Jurnal Ilmiah Pendidikan, Vol. 01 No. 1, 2017

Mujahidin, Anwar, Epistemologi Islam: Kedudukan Wahyu Sebagai Sumber Ilmu, Jurnal Ulumuna Studi Islam Vol. 17 No. 1, 2013

Hidayat, Ahmad Wahyu, Pemikiran Syekh Nawawi Al-Bantani dan Relevansinya di Era Modern, Jurnal AQLAM: 
Journal of Islam and Plurality Vol. 4, No. 2, 2019

Bakar, Abu, Konsep Toleransi dan Kebebasan Beragama, Jurnal TOLERANSI: Media Komunikasi Umat Bergama, Vol. 7, No. 2, 2015

Umar, Bukhari, Hadis Tarbawi (Pendidikan Dalam Pespektif Hadis), (Jakarta, AMZAH: 2012)

Bashori, Pemikiran Pendidikan Syekh Nawawi Al-Bantani, HIKMAH: Jurnal Pendidikan Islam, Vol. 6, No. 1,2017

Wahyudi, Dedi dan Siti Aisah, Aktualisasi Pendidikan Islam Dalam Pengelolaan Lingkungan Hidup: Studi Relasi Antara Pendidikan Islam dan Budaya Mistis Dalam Pelestarian Lingkungan, Tarbawiyah: Jurnal Ilmiah Pendidikan, Vol. 02 No. 01, 2018

Santi, Febri, Konsep Pendidikan Multikultural Dalam Pendidikan Islam, Turast: Jurnal Penelitian \& Pengabdian Vol. 4, No. 1, 2016

Hakim, Mohammad David dan Eni Fariyatul Fahyuni, Pendidikan Islam dalam Perspektif Syed Naquib AlAttas dan Relevansinya bagi Pengembangan Pendidikan Islam di Indonesia, Islamika: Jurnal Keislaman dan Ilmu Pendidikan Vol. 2, No. 1, 2020.

Buseri, Kamrani, Epistemologi Islam dan Reformasi Wawasan Pendidikan, Jurnal Ilmiah Peuradeun, Vol. 3, No. 1,2015

Nurmiyanti, Leni, Pendidikan Agama Islam Sebagai Pondasi Sosial Budaya Dalam Kemajmukan, ISTIGHNA, Vol. 1, No 2, 2018

Qomar, Mujamil, Epistemologi Pendidikan Islam, (Jakarta, Penerbit Erlangga, 2006)

Nizar, Samsul, Filasaft Pendidikan Islam Pendekatan Historis, Teoritis dan Praktis, (Jakarta: Ciputat Pers, 2002)
Abrasyi, Muhammad 'Atthiyyah, PrinsipPrinsip Dasar Pendidikan Islam (Bandung: Pustaka Setia, 2003)

Awwaliyah, Robiatul dan Hasan Baharun, Pendidikan Islam Dalam Sistem Pendidikan Nasional Robiatul Awwaliyah dan Hasan Baharun (Telaah Epistemologi Terhadap Problematika Pendidikan Islam), Jurnal Ilmiah DIDAKTIKA Vol. 19, No. 1, 2018

Pulungan, Suyuthi, Sejarah Peradaban Islam, (Jakarta: Amzah, 2018)

Sumihara, Pendidikan Islam dengan Nilai-nilai Budaya, Jurnal Adabiyah Vol. 12 No. 2, 2012

Yasyakur, M., Strategi Guru Pendidikan Aagama Islam Dalam Menanamkan Kedisiplinan Beribadah Sholat Lima Waktu, Edukasi Jurnal Pendidikan Islam Vol. 05, No. 1, 2016

Zaenal, Khalim dan Wan Zulkifli Wan Hassan, Pendekatan Islam Dalam Menangani Masalah Disiplin Tegar dalam Kalangan Pelajar Ssekolah: Kajian Kes, Journal of Islamic and Arabic Education, 1 (2) 2009

Ali, Mohammad Daud, Pendidikan Aagama Islam, (Depok: Rajawali Pers, 2018)

Muchsin, M. Bashori, et.al, Pendidikan Islam Humanistik; Alternatif Pembebasan Anak, (Bandung: PT Rafika Aditama, 2010)

Ibrahim, Ruslan, Pendidikan Multikultural: Era Pluralitas Agama, Jurnal Pendidikan Islam, el-Tarbawi, No. 1, Vol. 1, 2008

Ibrahim, Rustam, Pendidikan Multikultural: Pengertian, Prinsip, dan Relevansinya dengan Tujuan Pendidikan Islam, Jurnal Addin, Vol. 7, No. 1, 2013

Arif, Mahmud, Pendidikan Agama Islam Inklusif-Multikultural, Jurnal Pendidikan Islam, Vol. 1, No. 1, 2012 